\title{
Methods for Determination of the Stability Constants of Outer-sphere Complexes Using Measurements of Absorbance, Optical Rotation, and Circular Dichroism: A Spectroscopic Study of the Outer-sphere Complex between Trisethylenedi- amine-cobalt (III) Ion and Ethylenediaminetetraacetate
}

\author{
BENGT NORDEN
}

Division of Inorganic Chemistry, University of Lund, Box 740, S-220 07 Lund 7, Sweden

\begin{abstract}
The stability constant, $\beta_{1}$, of the first outer sphere complex between trisethylenediaminecobalt(III) $(=\mathrm{M})$ and ethylenediaminetetraacetate $\left(=\mathrm{H}_{2} \mathrm{Y}^{2-}=\mathrm{L}\right)$ has been determined at different ionic strengths, using different spectroscopic methods; measurement of absorbance in the ultra-violet, of circular dichroism, and of optical rotation. The metal compound (M) was kept in excess to assure that only the first complex was formed. At $I=0.1,0.5$, and $1 \mathrm{M}, \beta_{1}=420$, 50 , and $20 \mathrm{M}^{-1}$, respectively.

The corresponding data obtained with excess of ligand should, according to an often used method, indicate that only one associate was formed, but the " $\beta_{1}$ " values resulting from this method were only $50 \%$ of those obtained from the first mentioned one, and the corresponding moler absorption coefficients of the complex were about two times larger than with $M$ in excess. This discrepancy has been interpreted in terms of a further association. The corresponding stability constant of a second outer sphere complex has been estimated: $\beta_{8}=3 \times 10^{4}, 6 \times 10^{2}$, and $1 \times 10^{2} \mathrm{M}^{-2}$ at $I=0.1,0.5$, and $1 \mathrm{M}$, respectively. The unreliability has been indicated of taking linearity of the often used function $C_{\mathrm{I}} / \delta$ versus $C_{\mathrm{I}} \quad\left(C_{\mathrm{L}_{\mathrm{L}}}=\right.$ total ligand concentration, $\delta=$ measured spectroscopic difference between the solutions $C_{\mathrm{M}}, C_{\mathrm{L}}$ and $\left.C_{\mathrm{M}}, 0\right)$ as a proof for correct assumptions (e.g. one complex only).

The magnitudes of the stability constants and the spectroscopic results are discussed (absorptivity and molar circular dichroism spectra have been computed), and it is suggested that the "ionic" bonding is partly covalent.
\end{abstract}

Circular dichroism (CD) measurement has proved to be a sensitive tool to $G$ detect outer sphere association between dissymmetric transition-metal complexes and polarizable anions in water solution. ${ }^{1-7}$ In view of the recent finding that the change in the $\mathrm{CD}$ of cobalt(III)trisethylenediamine $\left(\mathrm{Co}(\mathrm{en})_{3}{ }^{3+}\right.$ ) 
when adding ethylenediaminetetraacetate $\left(\mathrm{H}_{2} \mathrm{Y}^{2-}\right)$ is totally due to the formation of an ordered ion-pair ${ }^{1,2}$ in which the ligand field is modified, it has been considered important to investigate the stability of the complex $\mathrm{Co}(\mathrm{en})_{3} \mathrm{H}_{2} \mathrm{Y}^{+}$. As certain other spectroscopic methods have been considered unreliable (optical rotation, ${ }^{7-10} \mathrm{UV}$-absorbance ${ }^{7}$ ) when used in this field, this investigation has been performed using on the one hand circular dichroism measurements, and on the other, data from UV-absorbance and optical rotation.

It has recently been reported that a photocatalytic reaction can take place between $\mathrm{Co}(\mathrm{en})_{3}{ }^{3+}$ and $\mathrm{H}_{2} \mathrm{Y}^{2-}$ (giving mainly $\mathrm{Co}(\mathrm{III}) \mathrm{Y}^{-}$), ${ }^{11}$ and it has been shown ${ }^{12}$ that the decreased reaction rate with increasing initial $\mathrm{H}_{2} \mathrm{Y}^{2-}$ concentration can in part be explained by a strong ionic strength dependence. The effect can thus to a great extent be cancelled by keeping a constant ionic strength.

The association has been investigated at a few different ionic strengths $\left(\mathrm{NaClO}_{4}\right)$. Bearing in mind the minimum in the expected general variation of $\beta_{1}$ with $I,{ }^{13}$ it was considered relevant to extend the ionic strength range, probably at the cost of a large deviation from the more ideal dependence obtained by Posey and Taube ${ }^{14}$ in their investigation of $\mathrm{Co}\left(\mathrm{NH}_{3}\right)_{6} \mathrm{SO}_{4}^{+}$.

\section{METHOD AND EXPERIMENTAL}

The equilibrium studied may be represented by

$$
\begin{gathered}
\mathrm{M}+\mathrm{L} \rightleftharpoons \mathrm{ML} \text {, with } \mathrm{M}=\mathrm{Co}(\mathrm{en})_{3}{ }^{3+} \text {, and } \mathrm{L}=\mathrm{H}_{2} \mathrm{Y}^{2-}, \\
\beta_{1}=[\mathrm{ML}] /[\mathrm{M}][\mathrm{L}]
\end{gathered}
$$

A method often used in studies on outer-sphere complexes ${ }^{11-17,26}$ for determining $\beta_{1}$ consists simply of the assumption that only one complex is formed. With $C_{\mathrm{L}}>>C_{\mathrm{M}}\left(C_{\mathrm{I}}\right.$ and $C_{\mathrm{M}}$ are the total concentrations of $\mathrm{L}$ and $\left.\mathrm{M}\right)$, and $C_{\mathrm{M}}$ constant, the function $C_{\mathrm{L}} / \delta$ gives a straight line when plotted versus $C_{\mathrm{L}}$. $\delta$ is the measured spectroscopic difference, $X\left(C_{\mathrm{M}}, C_{\mathrm{L}}\right)-X\left(C_{\mathrm{M}}, 0\right)$, between the solution $C_{\mathrm{M}}+C_{\mathrm{L}}$ and the one with only $C_{\mathrm{M}}$. If $x_{\mathrm{M}}$ and $x_{\mathrm{ML}}$ are the respective molar spectroscopic intensity entities of pure $M$ and $\mathrm{ML}$, the usual approximation is ${ }^{15-17}$

$$
C_{\mathrm{L}} / \delta=\frac{C_{\mathrm{L}}}{\left(x_{\mathrm{ML}}-x_{\mathrm{M}}\right) C_{\mathrm{M}}}+\frac{1}{\beta_{1}\left(x_{\mathrm{ML}_{1}}-x_{\mathrm{M}}\right) C_{\mathrm{M}}}
$$

$\beta_{1}$ is obtained as the ratio of slope to intercept of the resulting straight line. A straight line is often taken as a proof that the model and approximations are satisfactory (in this case and that discussed below). ${ }^{18,16}$

With the concepts introduced above, i.e. (1), and $\delta=X\left(C_{\mathrm{M}}, C_{\mathrm{I}_{1}}\right)-X\left(C_{\mathrm{M}}, 0\right)$, it follows that $\delta=\left(x_{\mathrm{ML}}-x_{\mathrm{M}}\right)[\mathrm{ML}],{ }^{*}$ and

$$
C_{\mathrm{L}} / \delta=\left(1+[\mathrm{L}] \beta_{1}\right) / \beta_{1} C_{\mathrm{M}}\left(x_{\mathrm{ML}_{\mathrm{L}}}-x_{\mathrm{M}}\right)+1 /\left(x_{\mathrm{ML}_{1}}-x_{\mathrm{M}}\right),
$$

provided that only one complex is formed. With $C_{\mathrm{L}} \gg C_{\mathrm{M}},[\mathrm{L}] \approx C_{\mathrm{L}}$, and one obtains

\footnotetext{
* If in $\delta=x_{\mathbf{M}}[\mathrm{M}]+x_{\mathbf{M I}}[\mathrm{ML}]+x_{\mathrm{L}}[\mathbf{L}]-x_{\mathrm{M}}([\mathbf{M}]+[\mathrm{ML}]), x_{\mathrm{L}}[\mathrm{L}]$ can be neglected.
} 


$$
C_{\mathrm{L}} / \delta=\frac{C_{\mathrm{L}_{1}}}{\left(x_{\mathrm{ML}}-x_{\mathrm{M}}\right) C_{\mathrm{M}}}+\frac{1}{\beta_{1}\left(x_{\mathrm{ML}_{1}}-x_{\mathrm{M}}\right) C_{\mathrm{M}}}+\frac{1}{x_{\mathrm{ML}_{1}}-x_{\mathrm{M}}}
$$

compared with the general expression (from (1) and $\delta=\left(x_{\mathrm{ML}}-x_{\mathrm{M}}\right)[\mathrm{ML}]$ and $\left.C_{\mathrm{M}}=[\mathrm{M}]+[\mathrm{ML}]\right):$

$$
C_{\mathrm{L}} / \delta=\frac{C_{\mathrm{L}}}{\left(x_{\mathrm{ML}}-x_{\mathrm{M}}\right) C_{\mathrm{M}}}+\frac{1}{\beta_{1}\left(x_{\mathrm{ML}}-x_{\mathrm{M}}\right) C_{\mathrm{M}}}+\frac{1}{\left(x_{\mathrm{ML}}-x_{\mathrm{M}}\right)}-\frac{\delta}{\left(x_{\mathrm{ML}}-x_{\mathrm{M}}\right)^{2} C_{\mathrm{M}}}
$$

The corresponding expressions, $\left(2^{\prime}\right),\left(3^{\prime}\right),\left(4^{\prime}\right)$, for the case of using $M$ in excess, and $C_{\mathrm{L}}$ constant, are obtained by changing $C_{\mathrm{M}}$ to $C_{\mathrm{L}}$ and $C_{\mathrm{L}_{4}}$ to $C_{\mathrm{M}}$ in (2), (3), and (4): e.g.

$$
C_{\mathrm{M}} / \delta=C_{\mathrm{M}} /\left(x_{\mathrm{ML}}-x_{\mathrm{M}}\right) C_{\mathrm{L}}+1 / \beta_{1}\left(x_{\mathrm{ML}}-x_{\mathrm{M}}\right) C_{\mathrm{L}}
$$

is the expression used in the wellknown investigation of Evans and Nancollas 18 on the halide complexes of $\mathrm{Co}(\mathrm{en})_{3}{ }^{3+}$ and $\mathrm{Co}\left(\mathrm{NH}_{3}\right)_{6}{ }^{3+}$.

After having tested the possibility of a deprotonization,

$$
\mathrm{Co}(\mathrm{en})_{3}{ }^{3+}+\mathrm{H}_{2} \mathrm{Y}^{2-} \rightarrow \mathrm{Co}(\mathrm{en})_{3} \mathrm{HY}+\mathrm{H}^{+} \text {, }
$$

by $\mathrm{pH}$ measurements ( $f f . \mathrm{p} .2520$ ), $\beta_{1}$ was determined by measuring UVabsorbance (A), circular dichroism (CD), and optical rotation (OR) of solutions containing excess of $\mathrm{M}$, and applying $\left(2^{\prime}\right)$ and $\left(4^{\prime}\right)$. The value of $x_{\mathrm{ML}_{1}}-x_{\mathrm{M}}$ obtained from $\left(2^{\prime}\right)$ was used in $\left(3^{\prime}\right)$ to obtain the function $C_{\mathrm{M}} / \delta+\delta /\left(x_{\mathrm{ML}}-x_{\mathrm{M}}\right)^{2} C_{\mathrm{L}}$ $-1 /\left(x_{M L}-x_{M}\right)$ of $\left(4^{\prime}\right)$. The corresponding procedures were also performed with excess of $\mathrm{L}$.

Experimental. The solutions were made up in $50 \mathrm{ml}$ measuring flasks from stock solutions of p.a. reagents (disodium versenate, Merck, sodium perchlorate, Fluka) and (+)trisethylenediaminecobalt(III) perchlorate (prepared in the usual way ${ }^{10}$ ). Only doubly distilled water was used.

The content of $\mathrm{Co}$ (II) in the $\mathrm{Co}(e n)_{3}\left(\mathrm{ClO}_{4}\right)_{3}$ was determined by measuring the absorbance at $660 \mathrm{~nm}$ of a solution, $0.15 \mathrm{M} \mathrm{Co}(\mathrm{en})_{3}\left(\mathrm{ClO}_{4}\right)_{3}, 9 \mathrm{M} \mathrm{HCl}\left(\varepsilon_{\mathrm{CoCle}}{ }^{2-}=475 \mathrm{M}^{-1} \mathrm{~cm}^{-1}\right.$ at this wavelength $\left.{ }^{20}\right)$. The sensitivity of the method was tested by adding small amounts of $\mathrm{CoCl}_{2}$. The contamination of $\mathrm{Co}$ (II) in the sample was thus shown to be less than $0.05 \%$.

When having $M$ in excess, $\delta_{\mathrm{A}}$ was directly measured as the absorbance difference between the sample $\left(C_{\mathrm{M}}, C_{\mathrm{L}}, x \mathrm{M} \mathrm{NaClO}_{4}\right)$ and $\left.\left(C_{\mathrm{M}}, 0, x \mathrm{M} \mathrm{NaClO}\right)_{4}\right)$. As $\delta_{\mathrm{A}}$ was very small, especially when the ionic strength was high, it was necessary to use a comparatively long cell path-length $(e . g .1 \mathrm{~cm})$. This demanded, however, that a large slit width region had to be used (e.g. $0.1-1 \mathrm{~mm}$ ). The slit variation was depressed as much as possible by compensation with different amplification of the photomultiplier signal. In the series with constant low metal concentration, the slit variation was kept equal to zero by using this method.

Two attempts have been made to increase the precision of the spectroscopic measurements. The first concerns the absorbance measurements and serves to minimize the error, just spoken of, due to slit variations; the absorbance differences were measured at different slit values, by using different amplification, and the curve, absorbance versus slit width, was extrapolated to a fixed slit value, constant throughout the series. In this way, an artificial "band monochromacy" was obtained.

The second improvement was a more precise CD determination. Instead of reading the absolute $C D$ on a recorded spectrum, the recorder signal was amplified 10 times, and the wavelength was kept constant at a value giving a sufficiently low absolute CD to be in the range of the recorder, but with a strong $C D$ effect due to the outer-sphere association (see, e.g., Ref. 1, Fig. 1, from which $450 \mathrm{~nm}$ appears to be a suitable wavelength). The error due to insufficient stability with time of the instrument was minimized by several rapid measurements, alternating between the two samples between which $\delta_{\mathrm{CD}}$ was to be determined.

Acta Chem. Scand. 25 (1971) No. 7 
Absorbance spectra were recorded with a Cary Model 15 recording spectrophotometer. The differential absorbance measurements were made with a Zeiss PMQ II instrument, the circular dichroism with a Roussel Jouan Dichrograph Model B, and (in the UV) with a Cary $60 \mathrm{OR}-\mathrm{CD}$ instrument, and the optical rotation with a Perkin Elmer Servopolarimeter PE 14l, equipped with an $\mathrm{He}-\mathrm{Ne}$ laser $(632.8 \mathrm{~nm})$. The UV-absorbance spectra were recorded using a $0.01 \mathrm{~cm}$ cell, the other absorbance measurements and the CD measurements by using $0.5,1$, and $2 \mathrm{~cm}$ cells (for $\mathrm{CD}$, also 4 and $5 \mathrm{~cm}$ cells were used). The OR measurements were performed in $10 \mathrm{~cm}$ cells. All cell-holders were thermostated $\left(25.00 \pm 0.005^{\circ} \mathrm{C}\right)$.

The stability constants, $\beta_{1}$, the actual molar spectroscopic differences and their respective standard deviations (denoted $\pm \sigma$ in the tables) have been computed with a Hewlett Packard desk computer, using a least squares method for a straight line.

Table 1. Experimental values of $\delta_{\mathrm{A}}, \delta_{\mathrm{CD}}$, and $\delta_{\mathrm{OR}}$, normalised to the dimension of $\mathrm{cm}^{-1}$.

\begin{tabular}{|c|c|c|c|c|c|c|c|c|c|c|}
\hline$C_{\mathrm{M}}>C_{\mathrm{L}}$ & \multicolumn{3}{|c|}{$\begin{array}{c}\text { Absorbance } \delta_{\mathrm{A}}\left(\mathrm{cm}^{-1}\right), \\
\text { slit corrected }\end{array}$} & \multicolumn{2}{c|}{$\begin{array}{c}\text { Circular dichroism } \\
\delta_{\mathrm{CD}}\left(\mathrm{cm}^{-1}\right) \times\left(-10^{4}\right)\end{array}$} & \multicolumn{3}{|c|}{$\begin{array}{c}\text { Optical rotation } \\
\delta_{\mathrm{OR}}\left(\mathrm{deg} . \mathrm{cm}^{-1}\right) \times\left(-10^{4}\right)\end{array}$} \\
\hline$C_{\mathrm{L}}(\mathrm{mM})$ & 4.00 & 4.00 & 4.00 & 4.00 & 4.00 & 4.00 & 4.00 & 4.00 & 4.00 & 4.00 \\
\hline$I(\mathrm{M})$ & 0.100 & 0.100 & 0.500 & 1.000 & 0.100 & 0.500 & 1.000 & 0.100 & 0.500 & 1.006 \\
\hline$\lambda(\mathrm{nm})$ & 265.0 & 270.0 & 265.0 & 265.0 & 450.0 & 450.0 & 450.0 & 632.8 & 632.8 & 632.8 \\
\hline & & & & & & & & & & \\
$C_{\mathrm{M}}(\mathrm{mM})$ & & & & & & & & & & \\
3.00 & $0.113,0.120$ & 0.054 & 0.045 & 0.021 & 4.5 & 1.2 & 0.49 & 19 & 6 & $2.5,1.5$ \\
6.00 & $0.184,0.184$ & 0.089 & 0.077 & 0.039 & 6.7 & 2.2 & 1.05 & 32 & 8 & $4.5,4.0$ \\
9.00 & $0.224,0.223$ & 0.107 & 0.103 & 0.055 & 7.8 & 3.1 & 1.35 & 38 & 15 & 6.0 \\
12.00 & $0.244,0.243$ & 0.117 & 0.126 & 0.071 & 9.0 & 3.8 & 1.80 & 41 & 17 & $7.0,7.5$ \\
15.00 & $0.236,0.227$ & 0.123 & 0.140 & 0.083 & 9.3 & 4.5 & 2.17 & 42 & 19 & 8.5 \\
18.00 & & & & & & 5.1 & & & 20 & \\
24.00 & & & & & & 6.0 & & & 25 & \\
\hline
\end{tabular}

\begin{tabular}{|c|c|c|c|c|c|}
\hline$C_{\mathrm{L}_{\mathrm{r}}}>C_{\mathrm{M}}$ & \multicolumn{3}{|c|}{$\begin{array}{l}\text { Absorbance } \delta_{\mathrm{A}}\left(\mathrm{cm}^{-1}\right) \\
\text { corrected for absorbance of free } \mathrm{L}\end{array}$} & $\begin{array}{c}\text { Circular dichroism } \\
\delta_{\mathrm{CD}}\left(\mathrm{cm}^{-1}\right) \times\left(-10^{4}\right)\end{array}$ & $\begin{array}{c}\text { Optical rotation } \\
\delta_{\mathrm{OR}}\left(\mathrm{deg} \cdot \mathrm{cm}^{-1}\right) \times\left(-10^{4}\right)\end{array}$ \\
\hline$C_{\mathrm{M}}(\mathrm{mM})$ & 3.00 & 3.00 & 3.00 & 6.00 & 6.00 \\
\hline$I(\mathrm{M})$ & 0.100 & 0.500 & 1.000 & 0.500 & 0.500 \\
\hline$\lambda(\mathrm{nm})$ & 265.0 & 265.0 & 265.0 & 450.0 & 632.8 \\
\hline $\begin{array}{c}C_{\mathrm{I}} \\
0.40 \\
1.00 \\
2.00 \\
3.00 \\
4.00 \\
5.00 \\
10.00 \\
20.00 \\
26.00 \\
30.00 \\
40.00 \\
50.00 \\
60.00 \\
70.00\end{array}$ & $\begin{array}{c}0.020 \\
0.032 \\
0.064 \\
0.094 \\
0.113 \\
0.134 \\
0.188 \\
0.238 \\
0.255 \\
-\end{array}$ & $\begin{array}{c}0.016 \\
0.026 \\
0.035 \\
0.044 \\
0.050 \\
0.082 \\
0.130 \\
- \\
0.166 \\
0.190 \\
0.212\end{array}$ & $\begin{array}{c}0.019 \\
- \\
0.041 \\
0.075 \\
- \\
0.103 \\
0.127 \\
0.149\end{array}$ & $\begin{array}{c}2.5 \\
\overline{5.0} \\
8.5 \\
-\overline{11.1} \\
13.3 \\
15.1 \\
16.7 \\
18.0\end{array}$ & $\begin{array}{c}8.0 \\
\overline{19.0} \\
33.0 \\
\overline{45.0} \\
51.0 \\
59.0 \\
66.0 \\
71.0\end{array}$ \\
\hline
\end{tabular}

Acta Chem. Scand. 25 (1971) No. 7 


\section{RESULTS}

When mixing solutions of $\mathrm{Co}(\mathrm{en})_{3}\left(\mathrm{ClO}_{4}\right)_{3}$ and $\mathrm{Na}_{2} \mathrm{H}_{2} \mathrm{Y}$ adjusted to identical $\mathrm{pH}\left(=4.5\right.$, a $\mathrm{pH}$ where approximately all versenate is present as $\left.\mathrm{H}_{2} \mathrm{Y}^{2-}\right)$, and with the same ionic strength, no significant $\mathrm{pH}$ change could be detected. An analysis of the accuracy of this determination showed that, e.g., a pH change of at least 2.5 was expected (when considering buffering effect and using a $\beta_{1}$ value from the results below) with a reaction

$$
\mathrm{Co}(\mathrm{en})_{3}{ }^{3+}+\mathrm{H}_{2} \mathrm{Y}^{2-} \rightarrow \mathrm{Co}(\mathrm{en})_{3} \mathrm{HY}+\mathrm{H}^{+} \text {. }
$$

As the measured difference was less than 0.1 , the reaction must be regarded as purely

$$
\mathrm{Co}(\mathrm{en})_{3}{ }^{3+}+\mathrm{H}_{2} \mathrm{Y}^{2-} \rightarrow \mathrm{Co}(\mathrm{en})_{3} \mathrm{H}_{2} \mathrm{Y}^{+}
$$

This is an interesting fact, considering the corresponding reaction between a heavy metal ion and $\mathrm{H}_{2} \mathrm{Y}^{2-}$, which is usually connected with a large $\mathrm{pH}$ decrease.

The main results of the spectroscopic measurements are given in Table 1, and partly illustrated in Figs. 1-6. In Fig. 1, a comparison is given between the two results obtained with and without correction by slit value extrapola-

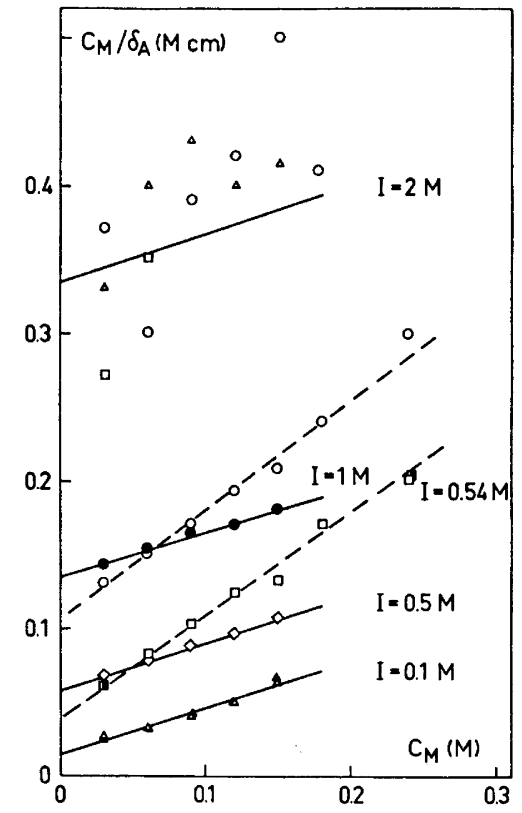

Fig. 1. The function $C_{\mathrm{M}} / \delta_{\mathrm{A}}$ at different ionic strengths $(0.100,0.500,0.542,1.000$, and $2.000 \mathrm{M})$. - depicts the line obtained when slit value extrapolation is used, - - - without such a correction. $\delta_{\mathrm{A}}$ determined at $265 \mathrm{~nm}$. $C_{\mathrm{L}}=4.00 \mathrm{mM}$.

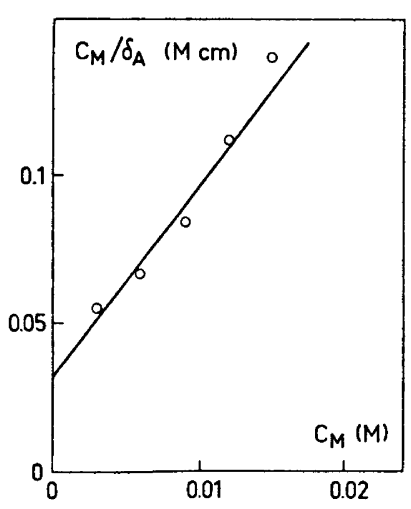

Fig. 2. $C_{\mathrm{M}} / \delta_{\mathrm{A}}$ at an ionic strength of $0.100 \mathrm{M}$ and at $270 \mathrm{~nm}$. Slit correction performed. $C_{\mathrm{L}_{\mathrm{L}}}=4.00 \mathrm{mM}$.

Acta Chem. Scand. 25 (1971) No. 7 
tion (see Experimental). The slopes of the lines $C_{\mathrm{M}} / \delta$ versus $C_{\mathrm{M}}$ show a considerably better constancy when using the extrapolated values for $\delta$. The results are generally greatly affected by the correction (except in the $I=0.1 \mathrm{M}$ case, where the large $\delta$ values permitted shorter path-lengths, and therefore a range with low slit values even without performing any extrapolation). It is noteworthy that the error due to slit variation (increasing with $C_{\mathrm{M}}$ ) does not appear as a non-linear curve, but gives a new straight line. This may be taken as an instructive warning to those who investigate, e.g., the association between a dye and a polypeptide, using differential absorbance measurements at high absorbances.

For the case of $I=0.1 \mathrm{M}$, there appears a slight deviation from linearity (Fig. 1). In Fig. 2, which depicts $C_{\mathrm{M}} / \delta_{\mathrm{A}}$ at $270 \mathrm{~nm}$, this deviation is confirmed.

It can be due to the fact that the approximation $\left(2^{\prime}\right)$ (or $\left(3^{\prime}\right)$ ) does not hold at lower $C_{\mathrm{M}}$, either depending on the inequality of $C_{\mathrm{M}}$ and [M], or that the assumption of one complex only is insufficient at this ionic strength. From the result presented in Table 2 it will emerge that the errors in the slopes of the lines (inversely proportional to $x_{M L}-x_{M}$ ) are in fact reduced, and the first mentioned explanation is thus satisfactory. This has been further confirmed by using the same $C_{\mathrm{M}}$ range, but a ten times lower $C_{\mathrm{L}_{\mathrm{L}}}$ (Fig. 3, Table 2).

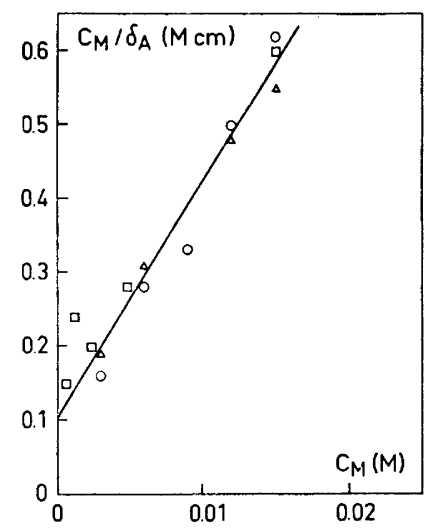

Fig. 3. $C_{\mathrm{M}} / \delta_{\mathrm{A}}$ at an ionic strength of 0.100 M. $\delta_{\mathrm{A}}$ at $265 \mathrm{~nm}$ without slit correction. $C_{\mathrm{L}}=0.400 \mathrm{mM}$.

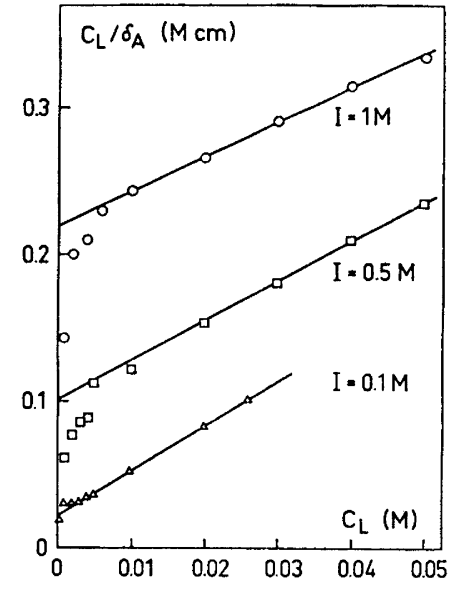

Fig. 4. $C_{\mathrm{L}} / \delta_{\mathrm{A}}$ at different ionic strengths $(0.100,0.500$, and $1.000 \mathrm{M}) . \delta_{\mathrm{A}}$ determined at $265 \mathrm{~nm} . C_{\mathrm{M}}=3.00 \mathrm{mM}$.

Though the measured differences were very small, approximately the same respective values of $\beta_{1}$ and $\varepsilon_{\mathrm{ML}}-\varepsilon_{\mathrm{M}}$ resulted (without slit correction), and there was no longer any marked tendency for the points to form a curved line.

The corresponding absorbance measurements on samples with low constant $C_{\mathrm{M}}$ and high varying $C_{\mathrm{I}}$ are given in Table 1 and Fig. 4. The absorbance data have been corrected for the small absorbance contributions from $L$. The results are given in Table 2.

Acta Chem. Scand. 25 (1971) No. 7 
Taable 2. Computed values of $\beta_{1}$ and $x_{M L}-x_{M}$ (in parenthesis). Values

\begin{tabular}{|c|c|c|c|c|c|}
\hline \multirow{2}{*}{\multicolumn{2}{|c|}{$\begin{array}{l}\vec{\downarrow} \quad \text { Method } \\
\quad \text { Medium }\end{array}$}} & \multicolumn{4}{|c|}{$C_{\mathrm{M}}>C_{\mathrm{I}_{1}}, C_{\mathrm{L}}=4.00 \mathrm{mM}$} \\
\hline & & $I=0.100 \mathrm{M}$ & $\begin{array}{l}I=0.100 \mathrm{M} \\
C_{\mathrm{L}_{\mathrm{L}}}=0.400 \mathrm{mM}\end{array}$ & $I=0.500 \mathrm{M}$ & $I=0.542 \mathrm{M}$ \\
\hline \multirow{3}{*}{$\begin{array}{l}\mathbf{A} \\
\mathbf{b} \\
\mathbf{s} \\
\mathbf{o} \\
\mathbf{r} \\
\mathbf{b} \\
\mathbf{a} \\
\mathbf{n} \\
\mathbf{c} \\
\boldsymbol{e}\end{array}$} & $\lambda=265 \mathrm{~nm}$ & $220 \pm 50$ & $253 \pm 71(83 \pm 6)$ & & $166 \pm 20(37 \pm 1)$ \\
\hline & $\begin{array}{l}\lambda=265 \mathrm{~nm} \\
\text { slit } \\
\text { extrapolated } \\
\text { to } 0.40 \mathrm{~mm}\end{array}$ & $\begin{array}{l}223 \pm 55 \quad(79 \pm 5) \\
580 \pm 200(71 \pm 3)\end{array}$ & & $\begin{array}{l}56 \pm 3(77 \pm 3) \\
78 \pm 5(70 \pm 2)\end{array}$ & \\
\hline & $\begin{array}{l}\lambda=270 \mathrm{~nm} \\
\text { slit } \\
\text { extrapolated } \\
\text { to } 0.40 \mathrm{~mm}\end{array}$ & $\begin{array}{l}160 \pm 22(44 \pm 2) \\
320 \pm 30(40 \pm 1)\end{array}$ & & & \\
\hline \multirow{2}{*}{ CD } & $\lambda=490 \mathrm{~nm}$ & $157 \pm 106(-0.32 \pm 0.07)$ & & & \\
\hline & $\lambda=430 \mathrm{~nm}$ & $119 \pm 47(-0.17 \pm 0.09)$ & & & \\
\hline \multicolumn{2}{|c|}{$\begin{array}{c}\text { CD difference } \\
\lambda=450 \mathrm{~nm}\end{array}$} & $\begin{array}{l}180 \pm 17(-0.322 \pm 0.011) \\
407 \pm 72(-0.287 \pm 0.009)\end{array}$ & & $\begin{array}{l}31.0 \pm 1.1(-0.355 \pm 0.009) \\
37.5 \pm 1.1(-0.33 \pm 0.01)\end{array}$ & \\
\hline \multicolumn{2}{|c|}{$\begin{array}{l}\mathrm{OR} \\
\quad \lambda=632.8 \mathrm{~nm}\end{array}$} & $\begin{array}{l}175 \pm 39(-15 \pm 1) \\
390 \pm 80(-13 \pm 1)\end{array}$ & & $\begin{array}{l}40 \pm 16(-13 \pm 3) \\
51 \pm 20(-12 \pm 3)\end{array}$ & \\
\hline & $\beta_{\text {mean }}\left(\mathbf{M}^{-1}\right)$ & \multicolumn{2}{|c|}{$420 \pm 50$} & $50 \pm 10$ & \\
\hline
\end{tabular}

All CD and OR measurements are given in Table 1, and the results in Table 2. Figs. 5 and 6 illustrate the good accuracy when using the differential CD method (see Experimental).

Figs. 9 and 10 show the absorption coefficient and molar circular dichroism spectra of the species M and ML, computed from recorded spectra, using the obtained values of Table 2. The ligand field absorbance band has not been depicted, as $\varepsilon_{\mathrm{M}}$ and $\varepsilon_{\mathrm{ML}}$ were found identical in this region. In Table 4, some of the data of the spectra are given.

\section{DISCUSSION}

A comparison of the stability constant values obtained with the different methods at an ionic strength of $0.1 \mathrm{M}$ (Table 2) does not indicate any method to be the "best". At this ionic strength, the high absorbance differences to be measured make it possible to work also at a wavelength with lower absorption coefficient $(270 \mathrm{~nm})$, apparently giving a lower standard deviation. However, the three rather close $\beta_{1}$ values from $265 \mathrm{~nm}$ (uncorrected: 220, 223, 
in italics correspond to the correction according to eqn. (4) or $\left(4^{\prime}\right)$.

\begin{tabular}{|c|c|c|c|c|}
\hline \multirow[b]{2}{*}{$I=1.000 \mathrm{M}$} & \multirow[b]{2}{*}{$I=2.000 \mathrm{M}$} & \multicolumn{3}{|c|}{$\begin{array}{c}C_{\mathrm{L}_{\mathrm{r}}}>C_{\mathrm{M}} \\
C_{\mathrm{M}}=3.00 \mathrm{mM}, \text { except for } \mathrm{CD} \text { and } \mathrm{OR} \text { values }\end{array}$} \\
\hline & & $I=0.100 \mathrm{M}$ & $I=0.500 \mathrm{M}$ & $I=1.000 \mathrm{M}$ \\
\hline $78 \pm 8(31 \pm 2)$ & & $\begin{array}{l}130 \pm 12(110 \pm 4) \\
208 \pm 24(102 \pm 3)\end{array}$ & $\begin{array}{l}26 \pm 2(125 \pm 7) \\
29 \pm 3(122 \pm 6)\end{array}$ & $10.5 \pm 0.2(144 \pm 2)$ \\
\hline $\begin{array}{l}23 \pm 2(81 \pm 7) \\
26 \pm 2(77 \pm 5)\end{array}$ & $10 \pm 2$ & & & \\
\hline $18 \pm 28(41 \pm 40)$ & & & & \\
\hline $\begin{array}{l}15.4 \pm 8(0.29 \pm 0.2) \\
18 \pm 8(-0.28 \pm 0.1)\end{array}$ & & & $\begin{array}{l}16.3 \pm 0.3(-0.563 \pm 0.004) \\
C_{M}=6.00 \mathrm{mM}\end{array}$ & \\
\hline $12 \pm 15(-16 \pm 8)$ & & & $\begin{array}{l}16.6 \pm 0.8(-22.0 \pm 0.6) \\
C_{\mathrm{M}}=6.00 \mathrm{mM}\end{array}$ & \\
\hline $20 \pm 5$ & $10 \pm 2$ & $210 \pm 20$ & $24 \pm 5$ & $11 \pm 1$ \\
\hline
\end{tabular}

and $253 \mathrm{M}^{-1}$, i.e. corrected, eqn. (4'), about $600 \mathrm{M}^{-1}$ ) cannot be neglected. A weighted mean of $450 \mathrm{M}^{-1}$ therefore compares rather well with the values obtained from CD differential or OR measurements.

It is remarkable that the $\beta_{1}$ values obtained from absorbance measurements seem to be larger than the corresponding (CD) or (OR) values. Different stability constants from different methods have sometimes been explained by the fact that different measuring techniques (e.g. spectroscopic and conductometrical) may show different ranges of sensitivity around the molecule, ${ }^{17,21,22}$ and therefore should account for different degrees of association. However, such arguments are inaccurate, as long as the special molar entities $x_{\mathrm{M}}, x_{\mathrm{ML}}$ (=absorptivity, ion conductivity etc.) do not depend of the actual concentration parameters, because a specific excentricity of the method should of course be included in the molar entity. In Fig. 7 are shown the results from measurements of the absorptivity at $265 \mathrm{~nm}$, the molar CD at $490 \mathrm{~nm}$, and the molar $\mathrm{OR}$ at $632.8 \mathrm{~nm}$ of $\mathrm{Co}(\mathrm{en})_{3}{ }^{3+}$ at different perchlorate concentrations. The effects of increasing "ionic strength" on the formal molar entities of absorbance, $\mathrm{CD}$ and $\mathrm{OR}$, all have the same signs as the corresponding effects Acta Chem. Scand. 25 (1971) No. 7 

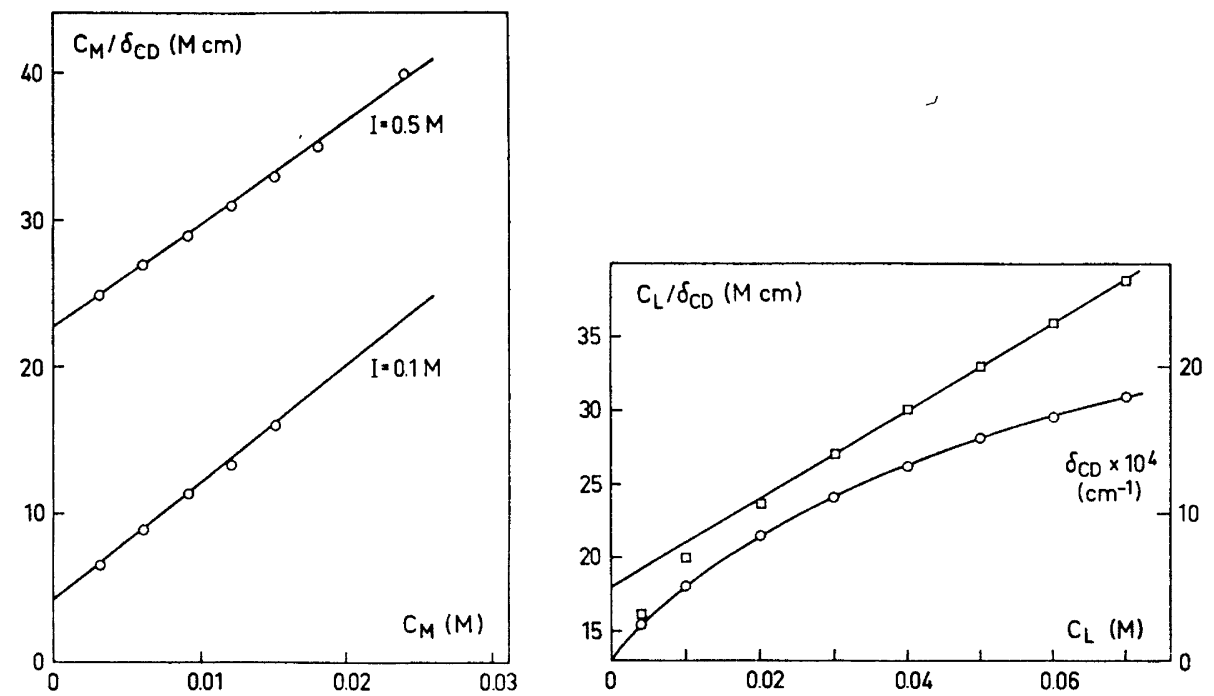

Fig. 5. $C_{\mathrm{M}} / \delta_{\mathrm{CD}}$ at $I=0.100$ and $0.500 \mathrm{M}$, $C_{\mathrm{L}}=4.00 \mathrm{mM}$. $\delta_{\mathrm{CD}}$ differentially measured Fig. 6. $\delta_{\mathrm{CD}}(\mathrm{O})$ at $450 \mathrm{~nm}$, and $C_{\mathrm{L}} / \delta_{\mathrm{CD}}$ at $450 \mathrm{~nm}$.

with increasing $C_{\mathrm{L}}$. However, in relation to the CD and OR effects, the absorptivity dependence of $C_{\mathrm{NaClO}_{4}}$ appears to be stronger than its dependence of $C_{\mathrm{L}}$. As the absorptivity at $470 \mathrm{~nm}$ is not at all affected by the perchlorate concentration, it is possible that the effect is caused by complex formation with perchlorate. Then it is not impossible that such a competing process,

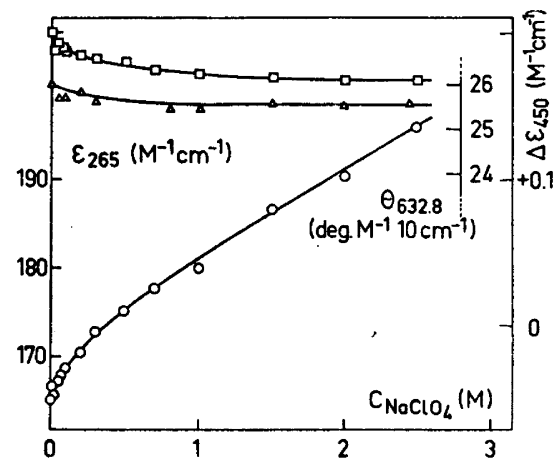

Fig. 7. Dependence of the formal molar entities of absorbance (O), circular dichroism $([])$ and optical rotation $(\triangle)$ of $\mathrm{Co}(\mathrm{en})_{3}\left(\mathrm{ClO}_{4}\right)_{3}$ on the $\mathrm{NaClO}_{4}$ concentration (at the wavelengths 265,490 , and $632.8 \mathrm{~nm}$, respectively).

neglected in the theoretical treatment, that influences the UV-absorbance only, could cause a difference between the stability constant values obtained from, e.g., absorbance and CD measurements. A corresponding reasoning can also be made from the assumption of a medium effect ${ }^{9,23,37}$ counteracting the $\mathrm{OR}$ and $\mathrm{CD}$ effects of the $\mathrm{M}-\mathrm{L}$ association. 
The result in Table 2 shows that the stability constant values obtained, using excess of $\mathrm{L}$, are less than half of those obtained with excess of $M$. As the last mentioned method does not require any one-complex-only condition (it could be assumed that no polynuclear complexes are formed), the values obtained with this method should better account for the stability constant of the first complex, the other values being affected by the formation of two or more complexes. In harmony with this and the lowered " $\beta_{1}$ " with excess of ligand is a corresponding elevation of the obtained difference " $x_{\mathrm{ML}}-x_{M}$ ".

Table 3. $\beta_{2}$ values from absorbance data.

\begin{tabular}{|c|c|c|c|c|c|c|c|}
\hline $\begin{array}{l}\varepsilon_{M L}-\varepsilon_{M} \\
\left(M^{-1} \mathrm{~cm}^{-1}\right)\end{array}$ & $\begin{array}{c}\varepsilon_{M_{2}}-\varepsilon_{M} \\
\left(M^{-1} \mathrm{~cm}^{-1}\right)\end{array}$ & $\begin{array}{c}C_{\mathrm{I}} \\
(\mathbf{m} \mathbf{M})\end{array}$ & $\begin{array}{c}C_{\mathrm{M}} \\
(\mathrm{mM})\end{array}$ & $\underset{\left(\mathrm{cm}^{-1}\right)}{\delta_{\mathrm{A}}}$ & $\begin{array}{c}I \\
(\mathrm{M})\end{array}$ & $\begin{array}{c}\beta_{1} \\
\left(\mathbf{M}^{-1}\right)\end{array}$ & $\begin{array}{c}\beta_{2} \\
\left(\mathbf{M}^{-2}\right)\end{array}$ \\
\hline 71 & 102 & $\begin{array}{l}10.0 \\
26.0\end{array}$ & $\begin{array}{l}3.00 \\
3.00\end{array}$ & $\begin{array}{l}0.188 \\
0.255\end{array}$ & 0.1 & 420 & $\begin{array}{l}2.0 \times 10^{4} \\
2.7 \times 10^{4}\end{array}$ \\
\hline 70 & 122 & $\begin{array}{l}30.0 \\
40.0 \\
50.0\end{array}$ & $\begin{array}{l}3.00 \\
3.00 \\
3.00\end{array}$ & $\begin{array}{l}0.166 \\
0.190 \\
0.212\end{array}$ & 0.5 & 50 & $\begin{array}{l}6.5 \times 10^{2} \\
6.3 \times 10^{2} \\
6.4 \times 10^{2}\end{array}$ \\
\hline 77 & 144 & $\begin{array}{l}40.0 \\
50.0\end{array}$ & $\begin{array}{l}3.00 \\
3.00\end{array}$ & $\begin{array}{l}0.127 \\
0.149\end{array}$ & 1.0 & 20 & $\begin{array}{l}1.0 \times 10^{2} \\
1.1 \times 10^{2}\end{array}$ \\
\hline
\end{tabular}

In Table 3, the $\beta_{2}$ values are given, estimated from the absorbance data with excess of $\mathrm{L}$, the $\beta_{1}$ and $\varepsilon_{\mathrm{MI}}-\varepsilon_{\mathrm{M}}$ values with excess of $\mathrm{M}$. With two complexes, the slope of the curve $C_{\mathrm{L}} / \delta$ versus $C_{\mathrm{L}}$ should approach $1 / C_{\mathrm{M}}\left(x_{\mathrm{ML}, \mathrm{s}}-x_{\mathrm{M}}\right)$, * i.e. the value of " $x_{\mathrm{ML}}-x_{\mathrm{M}}$ " from the excess of the $\mathrm{L}$ method (eqn. (2)) should be, actually, $x_{\mathrm{ML}_{\mathrm{I}}}-x_{\mathrm{M}}$. The almost doubled values of " $x_{M L}-x_{M}$ " from this method could thus well fit the theory that with two ligands, the charge transfer transition probability should be doubled. This is, however, based on the assumption of a superimposed charge transfer band, arising from the anion association. As will be pointed out below, this is not always the case.

From the observed $\delta_{\mathrm{x}}=X\left(C_{\mathrm{M}}, C_{\mathrm{L}}\right)-X\left(C_{\mathrm{M}}, 0\right)=\left(x_{\mathrm{ML}}-x_{\mathrm{M}}\right)[\mathrm{ML}]+\left(x_{\mathrm{ML}_{\mathbf{3}}}-\right.$ $\left.x_{\mathrm{M}}\right)\left[\mathrm{ML}_{2}\right]$ at a certain $C_{\mathrm{I}}$, the equations (1) and $C_{\mathrm{M}}=[\mathrm{M}]+[\mathrm{ML}]+\left[\mathrm{ML}_{2}\right]$ and the estimated $\beta_{1}$ and $\left(x_{\mathrm{ML}}-x_{\mathrm{M}}\right)$ values of $[\mathrm{ML}]$ and $\left[\mathrm{ML}_{2}\right]$ have been obtained, and $\beta_{2}=\left[\mathrm{ML}_{2}\right] /[\mathrm{M}][\mathrm{L}]^{2}$ computed.**

$$
\begin{aligned}
& * \lim _{[\mathrm{L}] \rightarrow \infty} \frac{\mathrm{d}\left(C_{\mathrm{L}} / \delta\right)}{\mathrm{d}[\mathrm{L}]}=\lim _{[\mathrm{L}] \rightarrow \infty} \frac{\mathrm{d}}{\mathrm{d}[\mathrm{L}]}\left(\frac{[\mathrm{L}]+[\mathrm{ML}]+2\left[\mathrm{ML}_{2}\right]}{\beta_{1}[\mathrm{M}][\mathrm{L}]\left(x_{\mathrm{ML}}-x_{\mathrm{M}}\right)+\beta_{2}[\mathrm{M}][\mathrm{L}]^{2}\left(x_{\mathrm{ML}_{2}}-x_{\mathrm{M}}\right)}\right)= \\
& \underset{\left[\mathrm{I}_{\mathrm{H}}\right] \rightarrow \infty}{\lim } \frac{\mathrm{d}}{\mathrm{d}[\mathrm{L}]}\left(\frac{\left(1+\beta_{1}[\mathrm{~L}]+\beta_{2}[\mathrm{~L}]^{2}\right) / C_{\mathrm{M}}+\beta_{1}+2 \beta_{2}[\mathrm{~L}]}{\beta_{1}\left(x_{\mathrm{ML}}-x_{\mathrm{M}}\right)+\beta_{2}[\mathrm{~L}]\left(x_{\mathrm{ML}, \mathrm{g}}-x_{\mathrm{M}}\right)}\right)=\frac{1}{\mathrm{C}_{\mathrm{M}}\left(x_{\mathrm{ML}, \mathrm{L}}-x_{\mathrm{M}}\right)} \\
& * *[\mathrm{ML}]=\frac{C_{\mathrm{M}}-\delta /\left(x_{\mathrm{ML}_{2}}-x_{\mathrm{M}}\right)}{1+1 / \beta_{1}[\mathrm{~L}]-\left(x_{\mathrm{ML}}-x_{\mathrm{M}}\right) /\left(x_{\mathrm{ML}_{2}}-x_{\mathrm{M}}\right)}
\end{aligned}
$$

First approximation: $[\mathrm{L}]=C_{\mathrm{L}}-C_{\mathrm{M}}$

Acta Chem. Scand. 25 (1971) No. 7 
Values of the stepwise association constant, $K_{2}=\beta_{2} / \beta_{1}$ were about 64,13 , and $5 \mathrm{M}^{-1}$ at ionic strengths of $0.1,0.5$, and $1 \mathrm{M}$. The corresponding ratios $\beta_{1} / K_{2}$ were 7,4 , and 4 . According to the electrostatic model, ${ }^{24,25}$ with the ionassociate as a result of Coulombic attraction only, $K_{2}(I=0)$ should be 100 times smaller than $\beta_{1}$ for the ion pair $\left[\mathrm{Co}\left(\mathrm{NH}_{3}\right)_{6}\right] \mathrm{SO}_{4}{ }^{+}$. As $\beta_{1} / K_{2}$ appears to increase with decreasing ionic strength (which is anyhow expected ${ }^{25}$ ), at zero ionic strength, 100 seems not to be an unreasonably high value.

An extrapolation of $\beta_{1}$ (Fig. 8) to zero ionic strength gives a value of at least $10^{4} \mathrm{M}^{-1}$, which may compare rather well with that of Posey and Taube ${ }^{14}$ for the sulphate complex $\left(10^{3}\right)$, as they measured with excess of ligand, thus probably obtaining too low a value.

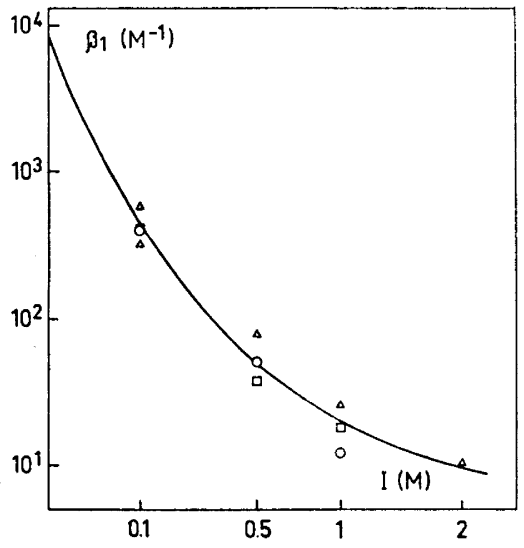

Fig. 8. The $\beta_{1}$ values versus the ionic strength ( $\Delta$ from absorbance measurements, $\square$ from CD, O from OR).

A common conception about the spectral behaviour at an association of outer sphere type is that the visible bands are left unchanged, but there appears a "new" band in the UV, due to charge transfer. ${ }^{6}$ In the typical cases of association between $\mathrm{Co}(\mathrm{en})_{3}{ }^{3+}$ and thiosulphate, phosphate, or iodide ions, which have suitable high-energy occupied orbitals, an interionic charge transfer absorption takes place, connected whith the appearance of a corresponding circular dichroism band. ${ }^{6,7}$ As a random orientation should not give rise to any rotational strength, the existence of such a CD band shows that the anion is stereospecifically bonded. The accessibility (overlap) of the actual orbitals to charge transfer makes the type of bonding formally close to what is called covalent bonding. A suggestion in this direction was first made by Larsson is his work on the outer sphere coordination of cobalt(III) ammine complexes. ${ }^{29,28,3}$

From Figs. 9 and 10 it appears that there is no interionic charge transfer, as the absorption coefficient (or circular dichroism) spectrum of $\mathrm{Co}(\mathrm{en})_{3} \mathrm{H}_{2} \mathrm{Y}^{+}$does not show any additional band, when compared with the spectrum of $\mathrm{Co}(\mathrm{en})_{3}{ }^{3+}$. However, it is remarkable that the absorptivity at the maximum (209 $\mathrm{nm}$ ) has decreased (though the band has become broader). This means that the anion interferes with the diamine orbitals, either through direct perturbation by its own orbitals, or indirectly via steric influence on the positions of diamine molecules. 


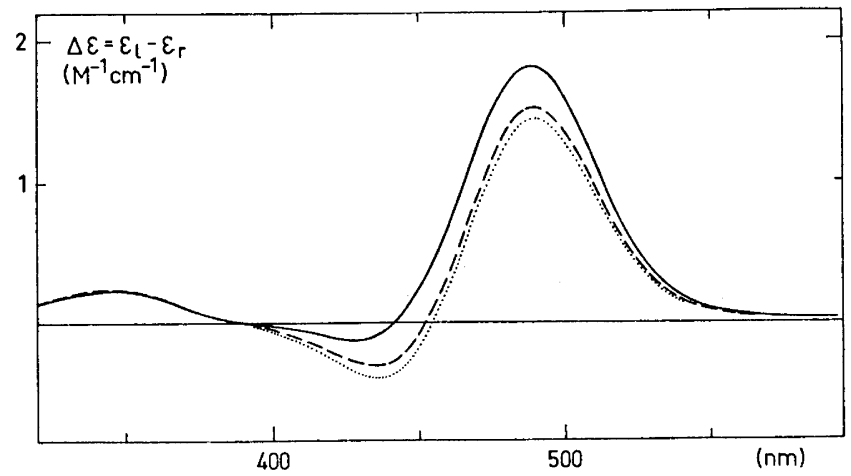

Fig. 9. Calculated molar circular dichroism spectra of $\mathrm{Co}(\mathrm{en})_{3}{ }^{3+}(-)$, and of $\mathrm{Co}(\mathrm{en})_{3} \mathrm{H}_{2} \mathrm{Y}^{+}\left({ }^{+}-, \mathrm{ML}_{\mathrm{I}}, \cdots, \mathrm{ML}_{\mathrm{II}}\right.$; see Discussion) of the ligand field bands.

In contrast to current work in this field ${ }^{30,31,27}$ we have not only found one negative $\mathrm{CD}$ band of $(+) \mathrm{Co}(\mathrm{en})_{3}{ }^{3+}$, corresponding to the $\mathrm{UV}$ absorption, but also a smaller positive band at shorter wavelengths (Fig. 10). Also, the

Fig. 10. Calculated absorptivity (above) and molar circular dichroism (below) spectra in the UV of $\mathrm{Co}(\mathrm{en})_{3}{ }^{3+}(-)$, and $\mathrm{Co}(\mathrm{en})_{3} \mathrm{H}_{2} \mathrm{Y}^{+}\left(---, \mathrm{ML}_{\mathrm{I}}, \ldots\right.$, $\mathrm{ML}_{\mathrm{II}}$; see Discussion), and of free $\mathrm{H}_{2} \mathrm{Y}^{2-}$ $(---)$.

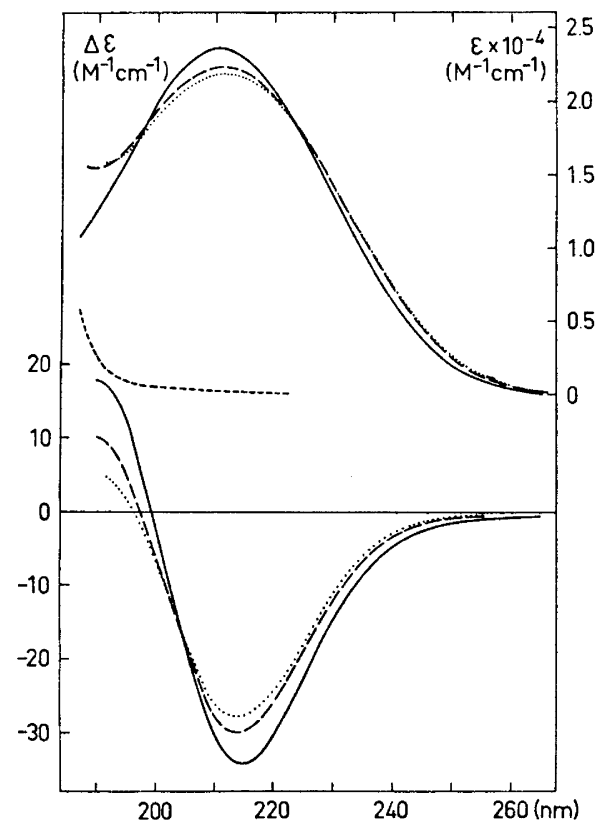

absorptivity of the $\mathrm{CT}$ band does not agree with that reported by Mason ${ }^{30}$ $\left(15 \times 10^{3} \mathrm{M}^{-1} \mathrm{~m}^{-1}\right)$, which in part may be due to the fact that different concentrations may have been used ( $c f$. Fig. 7).

Acta Chem. Scand. 25 (1971) No. 7 
The broadening of the absorption band may be regarded as an effect of a splitting into two or more bands, due to a lowered symmetry in the associate. At about $230 \mathrm{~nm}$, there appears in fact a diffuse shoulder. This can, of course, also be the effect of an interionic charge transfer ( $c f$. the positive CT CD band of $(+) \mathrm{Co}(\mathrm{en})_{3}$ phosphate $\left.{ }^{6}\right)$.

Due to the low accuracy in $\beta_{2}$, it has not been considered relevant to estimate any $\varepsilon_{\mathrm{MI}}$, or $\Delta \varepsilon_{\mathrm{ML},}$ spectra. However, from the recorded spectra of solutions containing high excess of $\mathrm{L}, \varepsilon_{\mathrm{ML}}$ and $\Delta \varepsilon_{\mathrm{ML}}$, spectra have been calculated, using the " $\beta_{1}$ " obtained with excess of L. These spectra $\left(\varepsilon_{\mathrm{ML}(\mathrm{II})}\right.$, $\Delta \varepsilon_{\mathrm{MI}_{\text {(II }} \text {, }}$ see Table 4) should then in comparison with the first obtained ones

Table 4. Absorption coefficients $(\varepsilon)$ and molar circular dichroisms $(\Delta \varepsilon)$ of $(+) \operatorname{Co}(e n)_{3^{3}}{ }^{3+}(=\mathbf{M})$ and $\mathrm{Co}(e n)_{3} \mathrm{H}_{2} \mathrm{Y}^{+}(=\mathrm{ML})$ at the band maxima. For $\mathrm{ML}_{\mathrm{I}}$ and $\mathrm{MI}_{\mathrm{II}}$, see Discussion. I and II represent the cases, $3.00 \mathrm{mM} \mathrm{M}, 4.00 \mathrm{mM} \mathrm{L}, I=0.030 \mathrm{M}, \beta_{1} \doteq 1.4 \times 10^{3} \mathrm{M}^{-1}$ (from Fig. 8) and $3.00 \mathrm{mM} \mathrm{M}, 26.00 \mathrm{mM} \mathrm{L}, I=0.096 \mathrm{M}, " \beta_{1} "=2.2 \times 10^{2} \mathrm{M}^{-1}$, respectively.

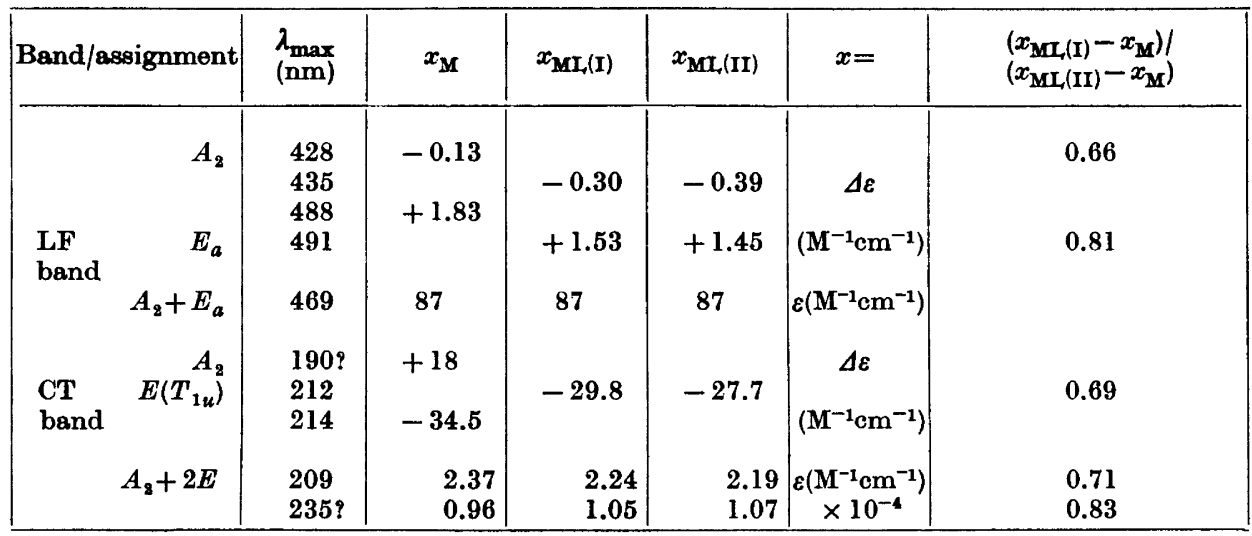

$\left.\varepsilon_{\mathrm{MI}(\mathrm{I})}, \Delta \varepsilon_{\mathrm{ML},(1)}\right)$ account for stronger spectral differences between ML and $\mathrm{ML}_{2}$. However, the ratio $\left(\varepsilon_{\mathrm{ML}(\mathrm{I})}-\varepsilon_{\mathrm{M}}\right) /\left(\varepsilon_{\mathrm{ML}(\mathrm{II})}-\varepsilon_{\mathrm{M}}\right)$ (or the corresponding CD ratio), the change of which should indicate a dissimilarity between the spectra, only exhibits small variations. These might as well be caused by the large medium difference, as by the presence of a second associate.'

However, both the values of $\Delta \varepsilon_{\mathrm{ML}}-\Delta \varepsilon_{\mathrm{M}}$ with/without excess of $\mathrm{L}$ (Table 2), and the result of comparing $\Delta \varepsilon_{\mathrm{ML} \text { (I) }}$ with $\Delta \varepsilon_{\mathrm{ML} \text { (II) }}$ (Figs. 9 and 10) show that the circular dichroism effect due to the association of one $\mathrm{H}_{2} \mathrm{Y}^{2-}$ is not counteracted, but rather reinforced, at a further association. This is interesting, in view of the statement of Larsson ${ }^{3,4}$ that an odd and an even number of anions in the complex should induce converse changes in the rotational strengths.

But let us return to the charge-transfer band at $209 \mathrm{~nm}$ (Fig. 10, Table 4). As the circular dichroism of a crystal, $2\left[(+) \mathrm{Co}(\mathrm{en})_{3} \mathrm{Cl}_{3}\right] \mathrm{NaCl}, 6 \mathrm{H}_{2} \mathrm{O},{ }^{34}$ has been found to increase when the (UV) radiation is propagated along the optic axis (三the $C_{3}$ axis), the CT transition (negative CD) has been assigned $E$ sym- 
metry. ${ }^{31,32}$ The coupling of charge-transfer excitations in the ligands (en $)^{33,32}$ gives rise to four transitions, one with $A_{1}\left(T_{2 u}\right)$, another with $A_{2}\left(T_{1 u}\right)$ and two with $E\left(T_{1 u}, T_{2 u}\right)$ symmetry (with respective parentages in parentheses). The $A_{1}$ transition is forbidden, and the $E\left(T_{2 u}\right)$ transition has only magnetic moment. As the negative CD band $(214 \mathrm{~nm})$ is thus due to the $E\left(T_{1 u}\right)$ transition, the positive band at shorter wavelength $(190 \mathrm{~nm})$ must be assigned $A_{2}\left(T_{1 u}\right)$.

According to coupled oscillator theory, ${ }^{35}$ the corresponding rotational strengths should be related by $R_{A_{2}\left(T_{1} u\right)}=-R_{E_{\left(T_{1 u}\right)}}=(4 / \sqrt{\overline{3}}) \pi v r D$, where $v$ is the transition frequency, $r$ is the distance between the metal ion and the ligand atom, and $D$ is the dipole strength of each of the six contributing excitations at the ligand atoms. The decrease in rotational strength of both the transitions (Fig. 10) at the association of $\mathrm{H}_{2} \mathrm{Y}^{2-}$ may thus suggest either a diminished $D$ or a diminished $\mathrm{Co}-\mathrm{N}$ distance.

Without closer knowledge of the absolute values of the rotational strengths of the transitions ( $c f$. , e.g., Ref. 2) it is, however, impossible to draw any selective conclusions. The change (Fig. 10) in the absorption band area (giving the total dipole-strength) ${ }^{36}$ appears to be small compared with the corresponding change in the band area in CD (giving the rotational strength), ${ }^{36}$ but as the observed CD bands are probably small rudiments from large rotational components, cancelling each other to a high extent, the relative rotational strength change may be small too, thus being totally explained by the change in dipole-strength.

This investigation gives, besides data on the remarkable association between $\mathrm{Co}(\mathrm{en})_{3}{ }^{3+}$ and EDTA, some information concerning the errors involved in a determination of the stability constant of an outer-sphere complex when using different methods and approximations. It is suggested that UV-absorbance or circular dichroism data, obtained from solutions containing excess of metal, preventing the formation of a second complex, should be used. When approximations in the equilibrium expression are used, these should be carefully controlled.

Acknowledgements. This work has been performed under the supervision of Dr. Ragnar Larsson, to whom I am indebted for unselfish help and valuable advice. The experimental work has been supported by a grant from the Swedish Natural Research Council.

\section{REFERENCES}

1. Nordén, B. Acta Chem. Scand. 23 (1969) 2925.

2. Larsson, R. and Nordén, B. Acta Chem. Scand. 24 (1970) 2681.

3. Larsson, R. Acta Chem. Scand. 21 (1961) 257.

4. Larsson, R., Mason, S. F. and Norman, B. J. J. Chem. Soc. A 1966301.

5. Larsson, R. and Norman, B. J. J. Inorg. Chem. 28 (1966) 1291.

6. Mason, S. F. and Norman, B. J. Proc. Chem. Soc. 1964339.

7. Smith, H. L. and Douglas, B. E. J. Am. Chem. Soc. 86 (1964) 3885.

8. Bjerrum, J. Adv. Chem. Ser. 62 (1967) 178 (the Alfred Werner Centennial Volume).

9. Bjerrum, J. and Romano, V. Det 13. Nordiske Kemikermode, Copenhagen 1968, p. 51.

10. Olsen, I. and Bjerrum, J. Acta Chem. Scand. 21 (1967) 1112.

11. Nordén, B. Acta Chem. Scand. 24 (1970) 1703.

12. Nordén, B. Acta Chem. Scand. 25 (1971). In press.

13. Gerding, P. Acta Chem. Scand. 22 (1968) 1283.

Acta Chem. Scand. 25 (1971) No. 7 
14. Posey, F. A. and Taube, H. J.Am. Chem. Soc. 78 (1956) 15.

15. Ogino, K. and Saito, U. Bull. Chem. Soc. Japan 40 (1967) 826.

16. Ogino, K. Bull. Chem. Soc. Japan 42 (1969) 447.

17. Tanaka, N. and Kobayashi, Y. Proc. Int. Meeting, 10th ICCC, Nikko, Japan 1967, p. 25.

18. Evans, M. G. and Nancollas, G. H. Trans. Faraday Soc. 49 (1953) 363.

19. Broomhead, J. A., Dwyer, F. P. and Hogarth, J. W. Inorg. Syn. 6 (1960) 186.

20. Spees, S. T. and Adamson, A. W. Inorg. Chem. 1 (1962) 531.

21. Prue, J. E. Proc. 3rd Symp. Coordination Chem., Debrecen 1970, p. 25.

22. Cohen, S. R. J. Phys. Chem. 61 (1957) 1670.

23. Bagger, S. Licentiatavhandling, The Technical University of Denmark, Copenhagen 1964 .

24. Bjerrum, N. Kgl. Danske Videnskab. Selskab, Mat.-Fys. Medd. 7 (1926) No. 9.

25. Bjerrum, J. Proc. 3rd Symp. Coordination Chem., Debrecen 1970. In press.

26. Linhard, M. Z. Elektrochem. 50 (1944) 224.

27. Mason, S. F. and Norman, B. J. J. Chem. Soc. A 1966307.

28. Larsson, R. and Norman, B. J. J. Inorg. Nucl. Chem. 28 (1966).

29. Larsson, R. and Tobiason, I. Acta Chem. Scand. 16 (1962) 1919.

30. Mason, S. F. Quart. Rev. 17 (1963) 59.

31. McCaffery, A. J. and Mason, S. F. Mol. Phys. 6 (1963) 359.

32. Ballard, R. E., McCaffery, A. J. and Mason, S. F. Proc. Chem. Soc. 1962331.

33. Kuhn, W. and Bein, K. Z. physik. Chem. (Leipzig) B 24 (1934) 335.

34. Mathieu, J.-P. J. Chim. Phys. 33 (1936) 78.

35. Moffitt, W. Proc. Natl. Acad. Sci. U.S. 42 (1956) 736.

36. Moscowitz, A. In Snatzke, G., Ed., Optical Rotatory Dispersion and Circular Dichroism in Organic Chemistry, Heyden \& Son, London 1965, p. 41.

37. Larsson, R. and Johansson, L. Proc. Symp. Coordination Chem., Tihany 1964, p. 31.

Received October 30, 1970. 